\title{
Д. ГРОХОЛЬСЬКИЙ
}

Компанія “CREDO-DIALOGUE”, пр. Незалежності, 95, Мінськ, 220043, Білорусь, Groholsky_D@credo-dialogue.com

\section{КЛАСИФІКАЦІЯ ХМАР ТОЧОК І СТВОРЕННЯ ЦИФРОВОЇ МОДЕЛІ МІСЦЕВОСТІ В НОВІЙ ВЕРСІЇ ПРОГРАМИ СRЕDО 3D СКАН}

Висвітлено технології оброблення даних лазерного сканування у програмному продукті “CREDO 3D СКАН”. Основну увагу приділено питанням класифікації хмар точок. Класифікація - важливий етап попередньої підготовки хмари точок, що дає змогу прискорити і частково автоматизувати подальші дії зі створення цифрової моделі місцевості (ЦММ).

Ключові слова: лазерне сканування; фотограмметрія; обробка хмар точок; класифікація хмар точок; CREDO 3D СКАН; цифрова модель місцевості.

У 2015 р. з’явилась перша версія програмного продукту для оброблення хмар точок від компанії “CREDODIALOGUE” CREDO 3D CKAH. Відтоді розвиток 3D СКАН не зупинявся і в жовтні 2019 р. вийшла чергова версія програми 3D СКАН 1.3. У цій версії розробники зробили акцент на загальне підвищення ефективності роботи і розвиток інструментів класифікації хмар точок.

Зазначимо, що програма дає змогу ефективно працювати 3 будь-якими хмарами точок: як отриманими в результаті лазерного сканування, так i фотограмметричними. Фотопанорами, одержувані в результаті роботи мобільних сканувальних комплексів, істотно доповнюють хмари точок і дозволяють ефективніше вирішувати завдання. Ортофотоплани, одержувані в ході фотограмметричних робіт, також можуть бути використані в роботі. У програмі 3D СКАН є великий інструментарій оброблення і векторизації зображень.

У межах цієї статті докладніше зупинимося на питаннях класифікації хмар точок у програмі 3D CKAH. Класифікація - важливий етап попередньої підготовки хмари точок, що дає змогу прискорити і частково автоматизувати подальші дії зі створення цифрової моделі місцевості (ЦММ). Під час класифікації виконується віднесення точок хмари до того чи іншого класифікаційного шару. Класифікаційні шари - це по суті групи точок хмари, об'єднані за логічними ознаками (рис. 1). Логіка вибору і призначення класифікаційних шарів може бути різною залежно від хмари точок i вирішуваних завдань. У програмі 3D CKAН закладено базові класифікаційні шари відповідно до стандарту ASPRS LAS. Стандарт передбачає, крім базових шарів, можливість створювати додаткові користувальницькі. Використання класифікації LAS як стандарту галузі гарантує збереження логіки класифікації хмари точок у різних системах оброблення хмар точок, які дотримуються стандарту LAS.

Отже, під час класифікації хмари точок виконується поділ точок хмари на групи згідно з належністю до того чи іншого типу об'єкта місцевості: рельєф, рослинність (низька, середня, висока), полотно автомобільної дороги, ЛЕП, огорожі, будівлі. Такий поділ точок дає змогу підвищити загальну ефективність роботи 3 хмарою: можна вибрати відображення хмари 3 розфарбуванням за верствами, управляти видимістю окремих шарів, використовувати точки певних верств у алгоритмах розпізнавання об’єктів.

Важливою перевагою використання класифікації $\epsilon$ й істотне підвищення швидкості роботи з хмарами точок, а також економія місця на диску: можна вирішувати різні завдання 3 точками, наприклад, тільки рельєфу (вирішуючи завдання моделювання рельєфу), тільки ЛЕП або будівель (працюючи над відображенням ситуації), маючи тільки одне - вихідну хмару точок з виконаної класифікації.

Під час виконання робіт зі створення ЦММ за хмарами точок першим завданням $\epsilon$ виділення (класифікація) рельєфу - точок хмари, що належать до земної поверхні. Точки шумів нижче від рельєфу можуть призвести до некоректної класифікації рельєфу, тому необхідно попередньо їх видалити або класифікувати як шум і вилучити 3 подальшого оброблення. Варто зазначити, що в новій версії 3D СКАН видалення і зміна шару окремих точок і груп точок - дуже швидка й ефективна операція, що дає змогу в ручному режимі уточнювати і коригувати результати автоматичних алгоритмів класифікації точок хмари. Для видалення або класифікації точок шуму в програмі передбачено команди, що виконують пошук як шумів нижче від рельєфу, так і ізольованих точок незалежно від їх розташування у хмарі. Отже, використовуючи автоматичні алгоритми та інструменти ручного оброблення, усувають точки шуму. Наступним етапом класифікації є безпосередньо класифікація рельєфу. Програма дає змогу ефективно класифікувати рельєф у різних умовах на різних типах хмар, зокрема фотограмметричних, коректно виконувати класифікацію рельєфу на кар'єрах із крутими схилами. У програмі реалізовано три потужні алгоритми виділення рельєфу: по геометричних пропорціях об'єктів, по куту піднесення сусідніх точок, адаптивний тріангуляційний фільтр. Кожен із них має переваги на різних типах хмар і місцевості. Використання інструменту класифікації дає змогу ефективно виконувати виділення рельєфу в кілька проходів комбінацією різних алгоритмів і параметрів. У новій версії 3D СКАН реалізовано узагальнений підхід до операцій над хмарами точок. Він дозволяє максимально гнучко використовувати всі наявні можливості оброблення хмар точок.

Для всіх команд, що виконують класифікацію чи внесення змін до точок хмари, а також використовують хмару точок як джерело інформації, передбачений універсальний підхід до налаштування (рис. 2). Параметри для зручності розділено на три логічні групи: дія, умова, алгоритм. У першій групі налаштовують дії з точками в результаті роботи алгоритму: окремо для точок, які відповідають критерію (в нашому випадку це точки 
рельєфу), і тих, що не відповідають. Можна модифікувати поточну хмару, а також створити копію і виконувати модифікацію у ній. Точки можуть бути виділені, видалені, їм призначено шар або колір. Друга група дає змогу задавати обмеження для алгоритму: використовувати точки в заданому контурі, точки певних верств або тільки виділені точки. Третя група - параметри конкретного алгоритму, що запускається командою. Отже, програма дає змогу максимально гнучко налаштовувати алгоритми для досягнення результату.

Виділення - ще один потужний інструмент, що допомагає у роботі з хмарами. Його зручно використовувати для тимчасового групування точок, не порушуючи поточної класифікації. Виділеними можуть бути точки, що належать до різних класифікаційних верств. Виділення може використовуватися як умова алгоритмів обробки хмар і розпізнавання об’єктів, для візуалізації.

Повертаючись до питання класифікації рельєфу, зазначу, що здебільшого алгоритми автоматичної класифікації рельєфу забезпечують хороший результат. Для складнихвипадків,наприклад,ділянокфотограмметричних хмар точок із рослинністю, яка формує “пагорби” з точок з пологими схилами без точок рельєфу під рослинністю, реалізована функціональність класифікації рельєфу із заданням опорної поверхні за допомогою 3D-контуру по периметру нерельєфної ділянки. Остаточне уточнення класифікації (за необхідності) може бути виконано в ручному режимі. Зазначимо, що алгоритми класифікації рельєфу як рельєф можуть використовувати точки, отримані за допомогою інструментального знімання та попереднього імпорту в програму. Ця можливість дає змогу істотно поліпшити якість класифікації рельєфу на ділянках із густою рослинністю.

3D СКАН дає змогу в автоматичному режимі виконати класифікацію ЛЕП на стовпах і створити точкові та лінійні об’єкти за результатами розпізнавання. Розпізнавання ЛЕП ефективно працює як під час оброблення хмар точок із ЛЕП на відкритій місцевості, так і в складних міських умовах.

У новій версії 3D СКАН розробники особливу увагу приділили зручності та ефективності роботи 3 програмою. За відгуками користувачів програми, найбільше труднощів виникає у виборі параметрів алгоритмів класифікації і розпізнавання об’єктів. У новій версії 3D СКАН в деяких командах реалізовано концепцію попереднього перегляду результатів у реальному часі для поточного значення параметрів.

Одним із інструментів, які сповна реалізують цю концепцію, $є$ Граничний фільтр. Він дозволяє фільтрувати хмари точок за різними параметрами: значеннями координат, інтенсивності, кутом сканування, часом реєстрації, висотою над рельєфом, градієнтом ухилу, кривизною. У разі зміни порогового значення в реальному часі оновлюється хмара, і точки, що не проходять в порогові значення, ховаються. Як і у інших алгоритмів, у порогового фільтра використовується стандартне вікно параметрів, що дає змогу налаштувати дії з точками, що проходять і не проходять за критеріями фільтра. Попередньо виконавши розрахунок нормалей, можна швидко виділити точки вертикальних поверхонь i об'єктів із використанням порогового фільтра за градієнтом ухилу. Попередній перегляд дає змогу швидко підібрати порогові значення для отримання якісного результату. Точки вертикальних об’єктів можна класифікувати в окремий тимчасовий шар або виділити. Далі, використовуючи інструменти зміни точок в контурі, точки швидко розносять по відповідних верствах (бордюри, огорожі, стіни будівель й інші шари).

Граничний фільтр також дає змогу вирішувати окремі прикладні завдання. Наприклад, після розрахунку нормалей у розфарбуванні за кривизною чітко проявляються дефекти дорожнього полотна, доволі добре видно кромки. За допомогою порогового фільтра за кривизною можна класифікувати точки дефектів, крайок та інші аномалії на полотні (рис. 4).

Моделювання рельєфу і ситуації за попередньо класифікованою хмарою виконується за допомогою різних автоматизованих інструментів, що дають змогу швидко й ефективно отримати кінцевий результат цифрову модель місцевості.

Для моделювання рельєфу вихідними даними $є$ попередньо класифіковані як рельєф точки хмари. За точками шару Рельєф виконується адаптивне проріджування, яке дозволяє класифікувати як каркас ключові точки, що визначають рельєф місцевості. На рівних і спокійних ділянках поверхні залишиться мінімальна кількість точок, яку визначає користувач, а на переломах і мікроформах рельєфу буде збережено необхідну для передавання форми цих об’єктів кількість точок. Класифіковані у такий спосіб ключові рельєфні точки хмари формують модельні точки і за ними будують поверхню.

Попередня класифікація вертикальних об'єктів слугує основою автоматизованого створення векторних об'єктів ситуації за хмарою точок. У програмі 3D CKAH реалізовано кілька функцій, що дають змогу автоматично векторизувати окремі елементи за хмарою точок: розпізнавання 3D ліній, розпізнавання ліній за проєкцією точок на площину, розпізнавання об'єктів зі складним перетином, формування растра за хмарою точок із подальшою векторизацією отриманого зображення (рис. 6).

У поточній версії програми істотно розвинені методи створення і редагування об'єктів. Важливою особливістю нової версії $€$ повноцінний функціонал роботи 3 геометрією у 3D вікнах і вікні динамічного діаметра. Як і у вікні План, можливе створення і редагування точкових, лінійних і майданних об'єктів: додавання, переміщення i видалення вузлів, переміщення об'єктів із базовою точкою, інші операції редагування.

Програма 3D CKАН безперервно розвивається. Планується як подальший розвиток спільних інструментів роботи в програмі, так i нових автоматизованих методів, які дадуть змогу підвищити ефективність роботи із хмарами точок і якість формованої цифрової моделі місцевості. Найближчим часом заплановано додати функціональність розрахунку обсягів за хмарами точок. I, що найголовніше, розробка, як і раніше, враховуватиме відгуки і побажання як досвідчених користувачів програми, так і тих, хто тільки починає працювати із хмарами точок і шукає програмний продукт для вирішення своїх завдань. 


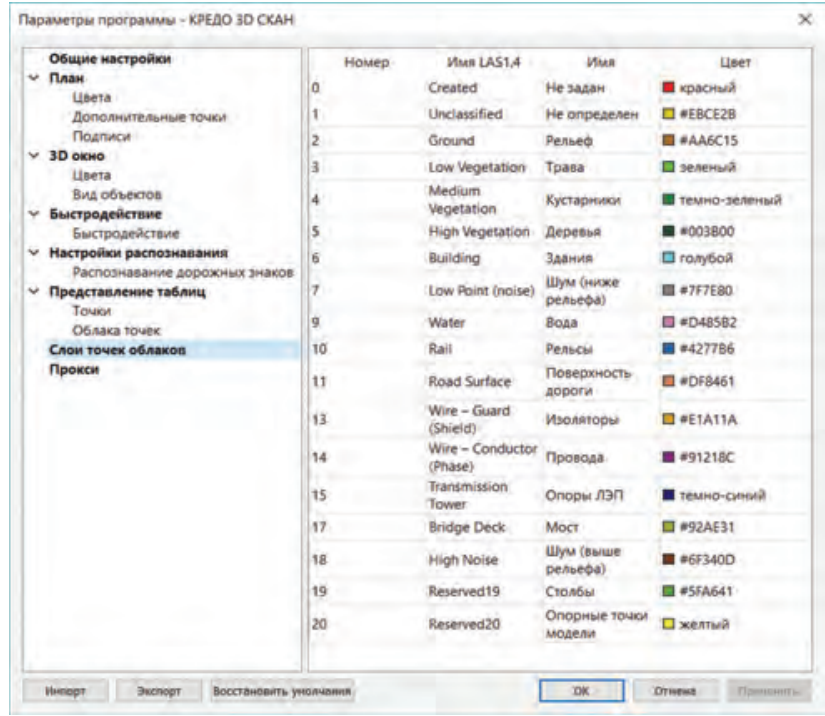

Рис. 1. Класифікаційні шари

\begin{tabular}{|c|c|}
\hline О Выделение рельефа - КРЕДО ЗD СКАН & \\
\hline Параметр & Значение \\
\hline \multicolumn{2}{|l|}{$\checkmark$ Действие } \\
\hline Применение & На месте \\
\hline рельеф & Q Задать слой \\
\hline Слой & \#2 (Рельеф) \\
\hline не рельеф & $\downarrow$ Не менять \\
\hline \multicolumn{2}{|l|}{$\checkmark$ Условие } \\
\hline Область & Все облако \\
\hline Точки & Все точки \\
\hline \multicolumn{2}{|l|}{$\checkmark$ Aлгоритм } \\
\hline Ша丿 сетки, M & 0.100 \\
\hline Тип фильтра & $=$ Размер объектов \\
\hline ТИН сглаживание & да \\
\hline Мин высота нерельефных объектов, м & 0,500 \\
\hline \multirow[t]{2}{*}{ Мин пропорция объектов (В/Ш) } & 0,500 \\
\hline & отмена \\
\hline
\end{tabular}

Рис. 2. Узагальнений підхід налаштувань параметрів алгоритмів

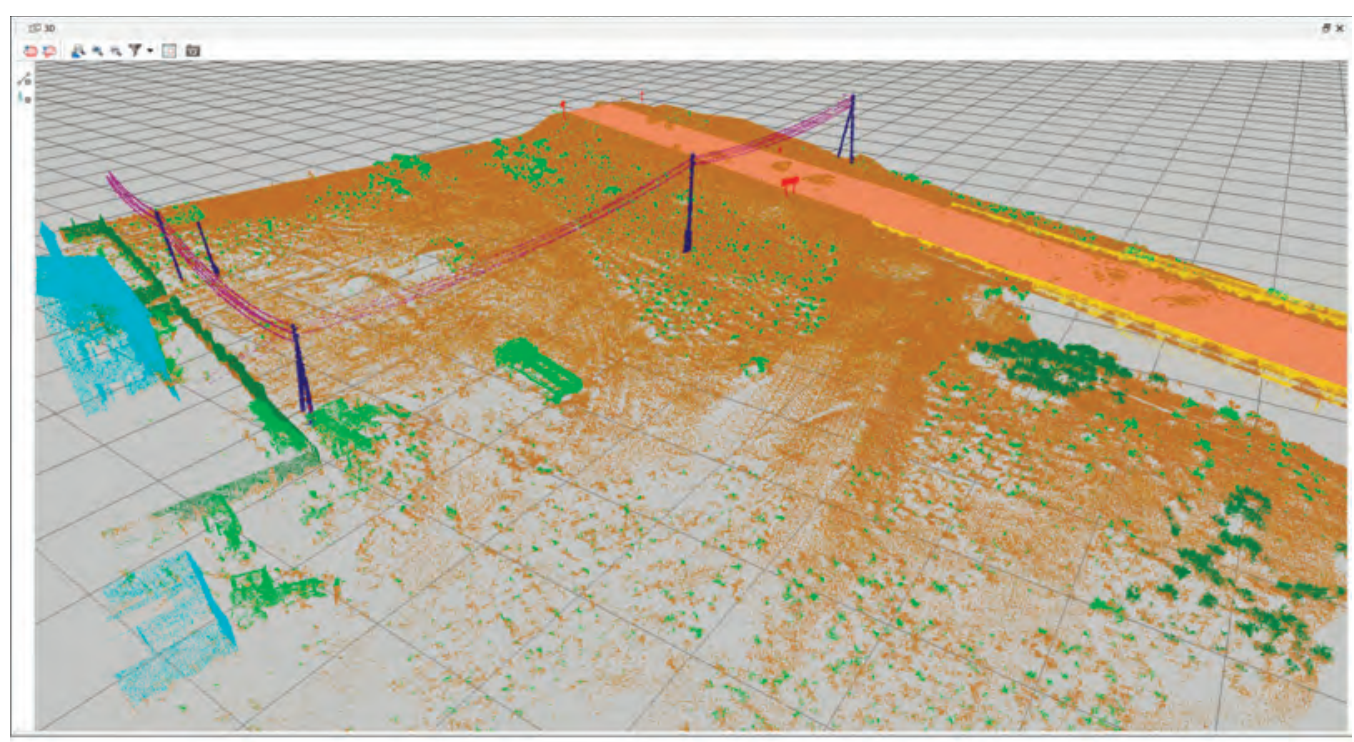

Рис. 3. Розфарбування хмари за шарами

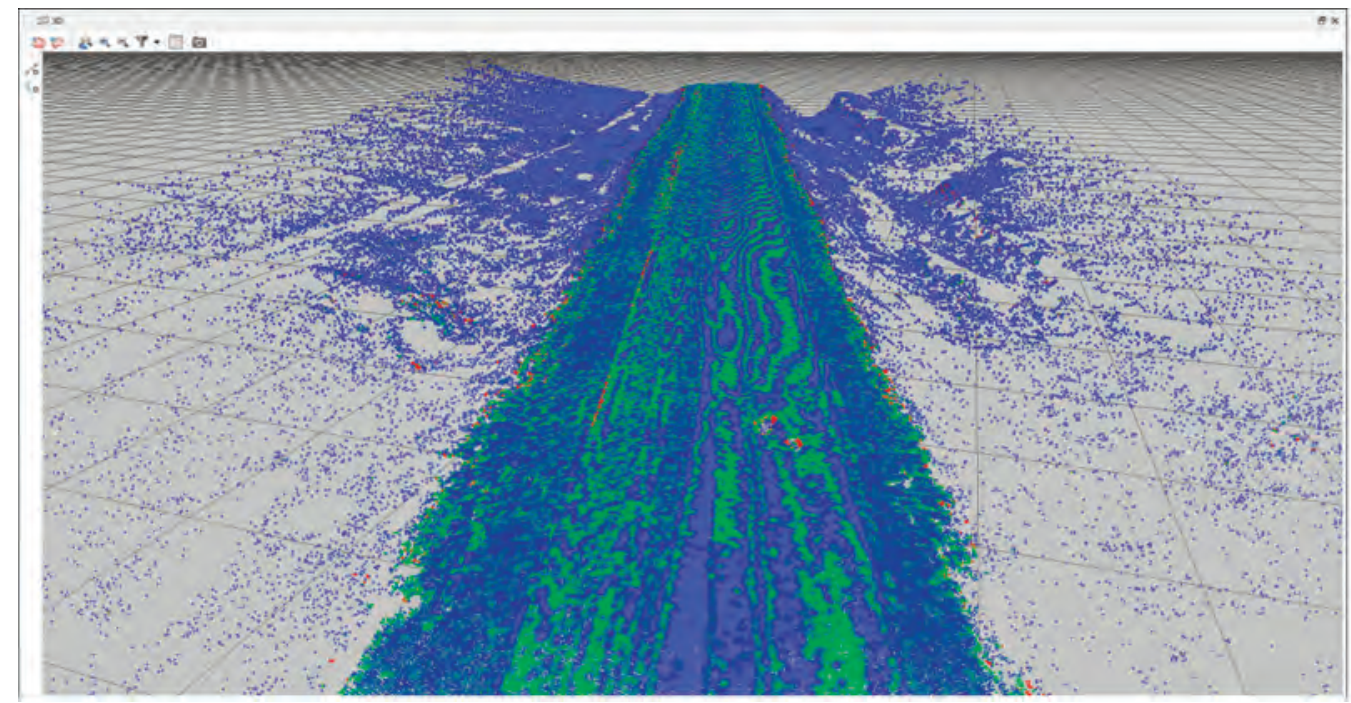

Рис. 4. Аналіз дорожнього полотна за кривизною 


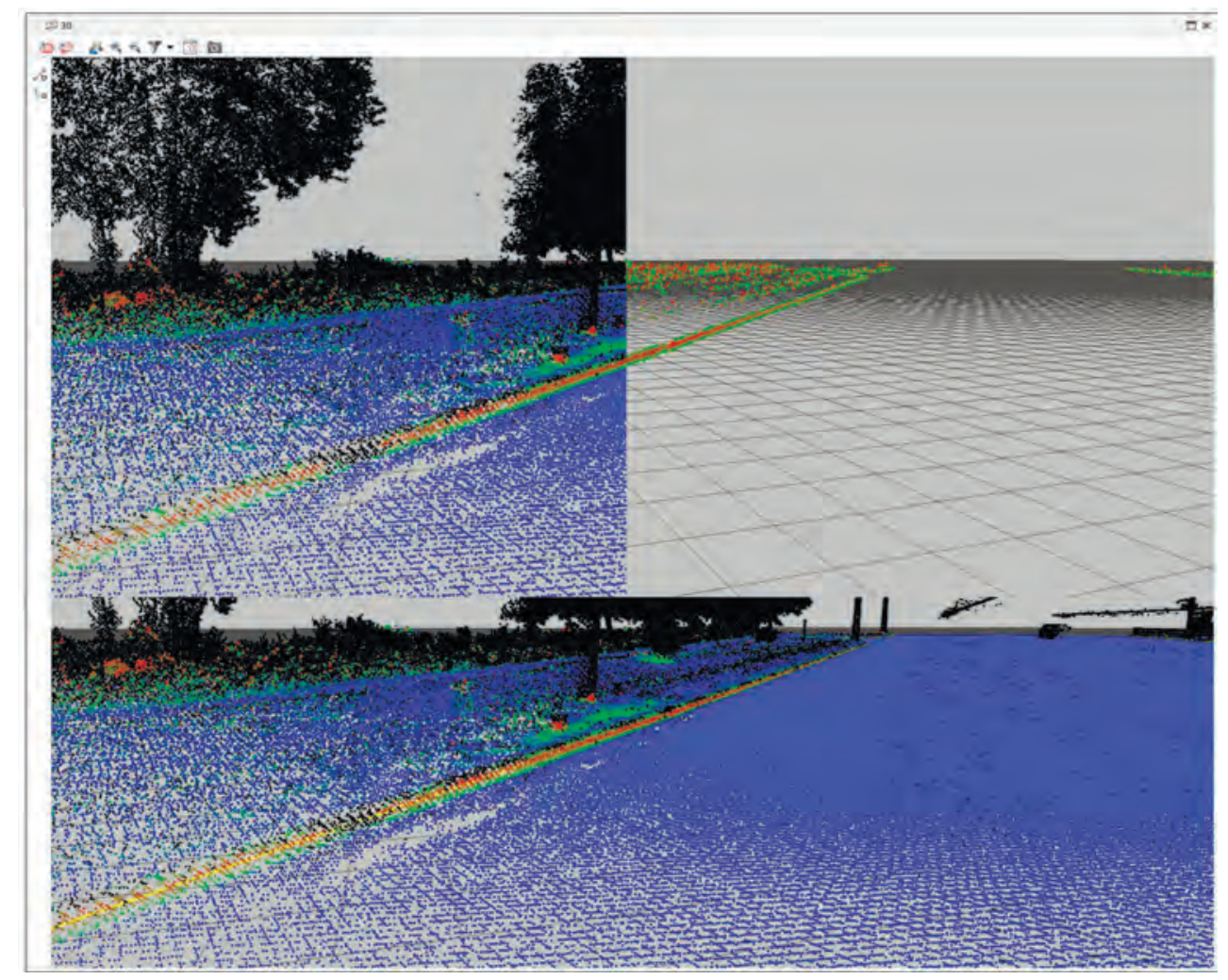

Рис. 5. Етапи розпізнавання бордюрів

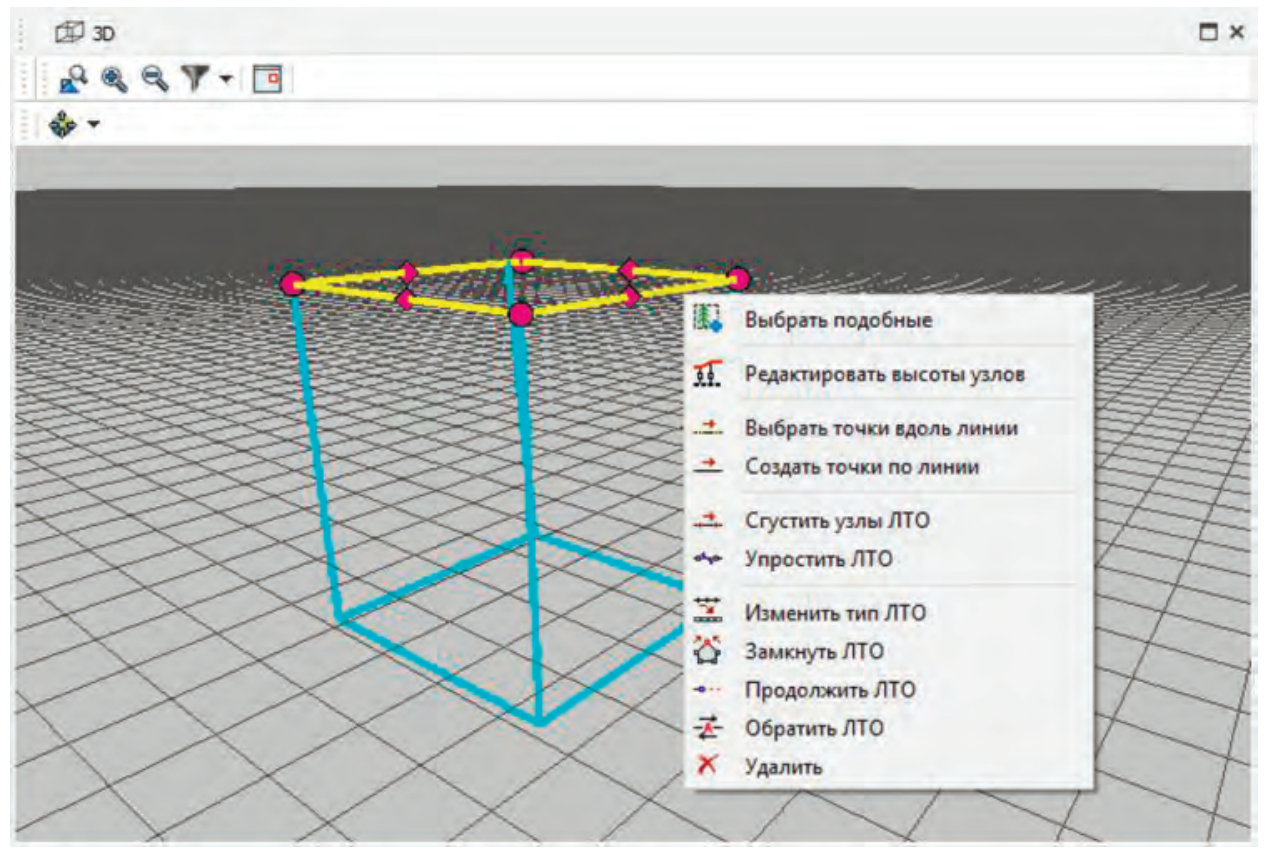

Рис. 6. Редагування об'єктів у ЗD

\section{HRAKHOLSKI}

Company “CREDO-DIALOGUE”, 95, pr. Nezalezhnosti, Minsk, 220043, Bilorus, e-mail: Groholsky_D@credo-dialogue.com

\section{CLASSIFICATION OF POINT CLOUDS AND THE CREATION OF A DIGITAL TERRAIN MODEL IN THE NEW VERSION OF THE CREDO 3D SCAN PROGRAM}

This article describes the technology laser scanning data processing in CREDO 3D SCAN software. The main attention is paid to the classification of point clouds. Classification is an important stage of pre-preparation of the point cloud, which allows user to speed up and partially automate subsequent actions of digital terrain model (DTM) creation.

Key words: laser scanning; photogrammetry; point cloud processing; point cloud classification; CREDO 3D SCAN; digital terrain model 